Aletria, Belo Horizonte, v. 29, n. 3, p. 353-357, 2019

\title{
BRITTO, Paulo Henriques. Nenhum mistério. São Paulo: Companhia das Letras, 2018. $70 \mathrm{p}$.
}

\section{Miguel Heitor Braga Vieira}

Universidade Estadual de Londrina (UEL), Londrina, Paraná / Brasil miguelvieira@uel.br

"No fim das contas, o desmanche é o meu tema", disse certa vez Paulo Henriques Britto em entrevista à revista Piauí. ${ }^{1}$ E completou: "O que constitui nossa realidade, na verdade, é muito frágil, deixa de existir sem mais nem menos". Um acréscimo a essa poética do desmanche é seu mais recente livro: Nenhum mistério - o sétimo de sua trajetória como poeta, lançado em agosto de 2018.

Trata-se de cinquenta e oito poemas que exploram e cavam um pouco mais fundo o sentido (ou a falta de) da vida e de seu entorno. Não nos enganemos pensando em algo transcendental quando falamos em sentido: a oportunidade, a imortalidade, o sublime e a metafísica aparecem, por exemplo, diretamente abordados em poemas que levam no título essas ideias abstratas e rarefeitas e podem ser agremiados nos primeiros versos de "Dos nomes": "O mundo está sempre se enchendo / de cacos vazios desse tipo. / Inúteis."2 Nesses versos já temos o tom de firme e constante recusa diante de significados fáceis. São invectivas contra os adornos de sentido elevado que se possa acrescentar a esses conceitos. As palavras de sua lírica tornam-se, assim, opacas, convocam o olhar e o raciocínio do leitor para si mesmas, especulando a respeito do real que é encerrado nelas. Desse modo, torna-se uma poesia negativa, de sondagem, uma poesia especulativa e de suspeita ao aparar excessos semânticos de conceitos que se tornam muletas instáveis da existência.

${ }^{1}$ BRITTO. Uma vida em tradução.

${ }^{2}$ BRITTO. Nenhum mistério, p. 63. 
Desde sua estreia em 1982 com Liturgia na matéria, a poesia de Britto é reconhecida por apresentar duas características: a recorrência à metalinguagem e o uso sistemático de formas fixas, sobretudo o soneto. No livro ora publicado não há tantos poemas metalinguísticos quanto havia nos anteriores. Antes poderíamos falar de uma incrustrada autoconsciência criativa diante dos materiais disponíveis para um acesso profundo ao real e suas consequências que propriamente em poemas metalinguísticos que colocam a literatura, a poesia, como tema visível.

Outro fato que se adiciona e se correlaciona a essa constatação é quanto ao manejo virtuosístico de formas criadas ou resgatadas pelo autor: os sonetetos, sonetilhos, sonetos mancos e sonetoides que apareceram em obras anteriores, como Trovar claro (1997), Macau (2003) e Tarde (2007), não surgem em Nenhum mistério. No entanto, predominam nesse livro, assim como naqueles, as composições curtas, em média com quatro estrofes e com versos que raramente ultrapassam as dez sílabas poéticas. Forma permanente, e que parece não se esgotar nas mãos do poeta, é a do soneto; por exemplo, o que segue:

Mirante

Há certos patamares na existência

de onde se divisam coisas não

belas, mas necessárias a quem pensa

que forjar uma significação

seja talvez - à falta de melhor -

uma maneira de dar arremate

àquilo que sobrevive à dor,

à confusão, à culpa, aos disparates.

Se o panorama, então, desapontar, lá de cima, quem teve em tempos planos

um sonho alpino, ao menos terá tido

o mérito menor de revelar

que a decepção, arrematando os anos, é o que há em matéria de sentido. ${ }^{3}$

${ }^{3}$ BRITTO. Nenhum mistério, p. 16. 
Quanto aos temas, além da metalinguagem, que ganha novos contornos, vê-se um aprofundamento do olhar pessimista, melancólico e deceptivo diante da existência, como aponta o poema acima. De certo modo, é uma virada que se percebia em seu livro anterior, Formas do nada, de 2012. Uma exceção a se notar é "À margem do Douro", em que uma tranquilidade e um bem-estar de cunho estoico proporcionam um momento de prazer de estar-em-si da voz poética ("permito-me, sem culpa, desfrutar / de pão, e queijo, e vinho, e vista, e ar"). ${ }^{4}$

De maneira geral, os poemas reforçam a forma, o tom e a postura de uma voz lírica desconfiada diante das construções de sentido pelo homem. Tudo isso por meio do desmonte da palavra poética que alcança uma dicção deliberadamente prosaica, mas peculiarmente erigida sob a forma de versos rigidamente metrificados. Mais de uma vez se falou da impressão de se ler prosa em versos na obra de Britto, com todos as ressalvas que essa afirmação possa receber para não incorrer em diminuição do valor dessa poesia. Insistindo na hipótese de desmanche, trata-se de dissolução de fundamentos da realidade, de sensações, apresentando as faltas de razões do que chamamos de vida nas mãos dos "deuses do acaso", como diz o verso que abre o volume. Há deuses, há um comando divino, mas esses deuses e esse comando situam-se exclusivamente no fortuito, no ocasional. No meio tempo de suas ações, o ser humano esperneia e atua, vivendo precariamente.

Um outro ponto a ser ressaltado e bastante divulgado nos poemas de Paulo Henriques Britto é o arremate que muitos deles trazem. De súbito, o texto que vinha de acordo com uma reflexão em linha reta subverte-se em uma espécie de coda que põe em xeque, contradiz, brinca, ironiza ou expressa indiferença melancólica diante do que foi dito anteriormente, desestabilizando e relativizando a mensagem e a forma ao funcionar como uma espécie de chave de ouro poética às avessas:

É uma espécie de véspera. Calados,

Os cômodos esperam o raiar

De alguma coisa como um dia. Ou não. ${ }^{5}$

Essa particularidade confere uma abertura maior às potencialidades interpretativas do texto. A impressão que temos é que a voz lírica assume

\footnotetext{
${ }^{4}$ BRITTO. Nenhum mistério, p. 56.

${ }^{5}$ BRITTO. Nenhum mistério, p. 29.
} 
nesse livro um tom mais direto, por vezes implacável, como ocorre no verso-desfecho "ligo o foda-se e a escrevo", 6 ou em "Tipo, 'Nada humano me é alheio'/ seu puto?".?

Por fim, há de se observar o elenco de referências e alusões encontradas em Nenhum mistério. Além do diálogo entre o título do livro e o poema "Uma arte" de Elizabeth Bishop (cujos primeiros versos dizem, na tradução do próprio Paulo Henriques Britto: "A arte de perder não é nenhum mistério; / tantas coisas contêm em si o acidente / de perdêlas, que perder não é nada sério"), ${ }^{8}$ percebemos pontos de contato com outros poetas brasileiros. Drummond ressoa nos poemas "VII" e "VIII" da série "Nenhum mistério": "Chega um momento em que as mãos / já não querem cumprir ordens", ${ }^{9}$ trecho que lembra "Os ombros suportam o mundo" e "Mãos dadas"; já os versos "que da pedra que há no caminho / se extraia o leite" 10 reportam-se ao famoso "No meio do caminho". Seria o caso de perceber também um eco drummondiano de "Áporo" ("Um inseto cava / cava sem alarme / perfurando a terra / sem achar escape", ${ }^{11}$ dizem os versos do poeta mineiro) no protagonismo da palavra em "Crisálida", de Britto: "Às vezes uma palavra / se limita à condição / de som oco e mero. Não / uma toca onde se encava // um talvez significado, / porém pura superfície / onde só se permitisse o óbvio mais deslavado". ${ }^{2}$ A sombra de João Cabral de Melo Neto se verifica na menção plausível da emoção em determinadas situações: "derramamentos nem um pouco cabralinos", ${ }^{13}$ indica o alexandrino de "Plaudite, amici". Ainda temos a ideia do desdobramento do $e u$, tão cara a Fernando Pessoa, a acompanhar o sujeito lírico "rumo a um outro eu / novo do cerne à casca / ou então, faute de mieux, / a uma boa máscara". ${ }^{14}$

Por meio dessas marcas a poesia de Paulo Henriques Britto prossegue como uma das mais ricas e interessantes da poesia brasileira contemporânea, resultando em aguda poética do desmanche.

\footnotetext{
${ }^{6}$ BRITTO. Nenhum mistério, p. 38.

${ }^{7}$ BRITTO. Nenhum mistério, p. 42.

${ }^{8}$ BISHOP. Poemas escolhidos, p. 363.

${ }^{9}$ BRITTO. Nenhum mistério, p. 26.

${ }^{10}$ BRITTO. Nenhum mistério, p. 27.

${ }^{11}$ ANDRADE. Antologia poética, p. 192.

${ }^{12}$ BRITTO. Nenhum mistério, p. 57.

${ }^{13}$ BRITTO. Nenhum mistério, p. 66.

${ }^{14}$ BRITTO. Nenhum mistério, p. 45.
} 
Aletria, Belo Horizonte, v. 29, n. 3, p. 353-357, 2019

\section{Referências}

ANDRADE, Carlos Drummond de. Antologia poética. Rio de Janeiro: Record, 1998.

BISHOP, Elizabeth. Poemas escolhidos. Tradução de Paulo Henriques Britto. São Paulo: Companhia das Letras, 2012.

BRITTO, Paulo Henriques Britto. Uma vida em tradução. Entrevista concedida a Mateus Baldi. Piaui, [S. l.], 19 out. 2017. Disponível em: https://piaui.folha.uol.com.br/uma-vida-em-traducao/. Acesso em: 29 mar. 2019.

BRITTO, Paulo Henriques. Nenhum mistério. São Paulo: Companhia das Letras, 2018. $70 \mathrm{p}$.

Recebido em: 29 de abril de 20019.

Aprovado em: 29 de julho de 2019. 